\title{
Plasma zinc as an indicator of zinc status in rats
}

\author{
By P. J. WILKINS, P. C. GREY AND I. E. DREOS'TI \\ Department of Biochemistry, University of Natal, Pietermaritzburg, \\ Republic of South Africa
}

(Received Io March I97I - Accepted $20 \not 3 u l y$ I97I)

\begin{abstract}
I. Standard zinc solutions for the atomic absorption analysis of rat plasma were prepared to contain $14 \%(\mathrm{w} / \mathrm{v})$ of sucrose. In this way the problems of sample nebulization were overcome with a minimum of manipulation before assay.

2. Plasma $\mathrm{Zn}$ concentrations in rats were found to fall by approximately $40 \%$ (from $\mathrm{r} \cdot 2$ to $0.7 \mu \mathrm{g} / \mathrm{ml})$ after $\times \mathrm{d}$ on a $\mathrm{Zn}$-deficient $(<0.25 \mathrm{ppm})$ diet. Thereafter, the fall became less marked and after $5 \mathrm{~d}$ the concentrations usually varied between 0.4 and $0.6 \mu \mathrm{g} / \mathrm{ml}$.

3. A single oral dose $(20-200 \mu \mathrm{g})$ of $\mathrm{Zn}$ was reflected in high plasma $\mathrm{Zn}$ concentrations in the depleted rats $I \cdot 75 \mathrm{~h}$ after dosing, but to a much lesser extent in animals receiving $10-60 \mathrm{ppm}$ $\mathrm{Zn}$ in their diet before dosing.

4. It is suggested that the plasma $\mathrm{Zn}$ response to a single oral dose of zinc sulphate may provide a useful method for the detection of a subnormal $\mathrm{Zn}$ status in individual farm animals without the necessity of determining breed norms.
\end{abstract}

The diagnosis of trace-element deficiencies in animals, especially at the marginal level, is notoriously difficult (Mills, Quarterman, Chesters, Williams \& Dalgarno, I969). At present most investigations of zinc status are based on plasma $\mathrm{Zn}$ concentrations, which have been shown to decline rapidly during states of dietary depletion (Mills, Dalgarno, Williams \& Quarterman, 1967; Dreosti, Tao \& Hurley, 1968). Unfortunately, individual analyses of plasma $\mathrm{Zn}$ are seldom unequivocal and studies of $\mathrm{Zn}$ status are usually complicated by the need to establish breed norms as well as the allowable variation between individuals.

In addition, although plasma appears to be ideally suited for analysis by atomic absorption spectroscopy, its viscosity renders it unsuitable for direct comparison with aqueous standards. Several procedures have been proposed whereby this problem may be overcome, but at present a simple and reliable method of analysis is not available.

Improved methods were therefore sought both for the assay of plasma $\mathrm{Zn}$ and for the early detection of $Z n$ deficiency in animals. The studies reported in this paper were performed on rats, but it is hoped that these findings may prove to be of value with larger animals where the problems of $\mathrm{Zn}$ deficiency are of more economic importance.

\section{EXPERIMENTAL AND RESULTS}

\section{Reagents}

All chemicals used were of analytical reagent grade and water was distilled and deionized through a multibed ion-exchange resin (model B I 25 Elgastat; Elga Products Ltd, Lane End, Buckinghamshire). 


\section{Animals and diets}

Female rats of the Wistar strain (I rO- $120 \mathrm{~g}$ ) were housed individually in stainlesssteel cages and given a diet consisting of sucrose $5 \mathrm{I} \%$, soya-bean meal $38.5 \%$ (solvent-extracted, containing $44 \%$ protein, obtained from Hind Bros \& Co. Itd, Durban), maize oil $6 \cdot 1 \%$, salt mix (Hurley \& Swenerton, 1966 ) $3.0 \%$, cod-liver oil $0.7 \%$, DL-methionine $0.5 \%$, choline chloride $0.2 \%$. The soya-bean meal was treated with ethylenediamine-tetraacetic acid (EDTA) to reduce its $\mathrm{Zn}$ content (Davis, Norris \& Kratzer, 1962; Swenerton \&.Hurley, 1968) and the entire diet was found to contain less than $0.25 \mathrm{ppm}$ of $\mathrm{Zn}$. Control animals received the same diet supplemented with $60 \mathrm{ppm}$ of $\mathrm{Zn}$ as zinc sulphate (Hurley, I969). A mixture of crystalline vitamins was supplied separately in sucrose three times a week (Hurley \& Swenerton, I966).

\section{Sampling techniques and analytical procedures}

Blood samples $(5 \mathrm{ml})$ for plasma $\mathrm{Zn}$ analyses were collected directly from the heart following ether anaesthesia. Clotting was avoided by the addition of $10 \mathrm{mg}$ sodium citrate/ml blood.

Viscosity measurements of plasma and sucrose solutions were made with an Ostwald viscometer at $25^{\circ}$.

$\mathrm{Zn}$ determinations were made on an atomic absorption spectrophotometer (model Pm Q II Zeiss; Oberkochen, Baden-Württemberg, West Germany) operating with a detection limit of $0.1 \mathrm{ppm}$ of $\mathrm{Zn}$ and a sensitivity of $0.2 \mathrm{ppm}$.

\section{Plasma viscosity measurements}

The viscosity of a pooled sample of plasma from ten rats was compared with the viscosity of a number of sucrose solutions (Table 1 ).

A $14 \%(\mathrm{w} / \mathrm{v})$ sucrose solution was found to have a viscosity at $25^{\circ}$ similar to that of rat plasma; standard $\mathrm{Zn}$ solutions $(0 . \mathrm{I}, 0.4, \mathrm{I} \cdot 0 \mathrm{ppm})$ were accordingly prepared to contain $14 \%$ sucrose.

Table I. Viscosity of pooled rat plasma and sucrose solutions expressed as flow times

(Mean values with their standard errors for five determinations on each sample performed at $25^{\circ}$ in an Ostwald viscometer)

$\begin{array}{cc}\text { Solution } & \text { Flow time (s) } \\ \text { Plasma } & 340 \pm 0.316 \\ \text { Sucrose } & 323 \pm 0.806 \\ 11 \% & 327 \pm 0.316 \\ 12 \% & 333 \pm 0.707 \\ 13 \% & 338 \pm 0.552 \\ 14 \% & 346 \pm 0.387 \\ 15 \% & 356 \pm 0.316 \\ 16 \% & \end{array}$




\section{Comparison of $Z n$ assay methods}

Pooled rat plasma was assayed by three methods. First, by the method of Prasad, Oberleas \& Halsted ( 1965 ) involving the precipitation of plasma proteins with trichloroacetic acid before assay. Secondly, by a procedure involving preliminary dilution ( $1: 4)$ of the sample with distilled water (Dreosti et al. I968) and, thirdly, by a method using untreated plasma and standard $\mathrm{Zn}$ solutions containing $14 \%$ sucrose. The findings presented in Table 2 indicate close agreement between the last two methods; the protcin precipitation technique, however, yielded somewhat higher results.

\section{Table 2. Comparison of methods for the estimation of zinc in plasma}

(Mean values with their standard errors for five determinations by each method)

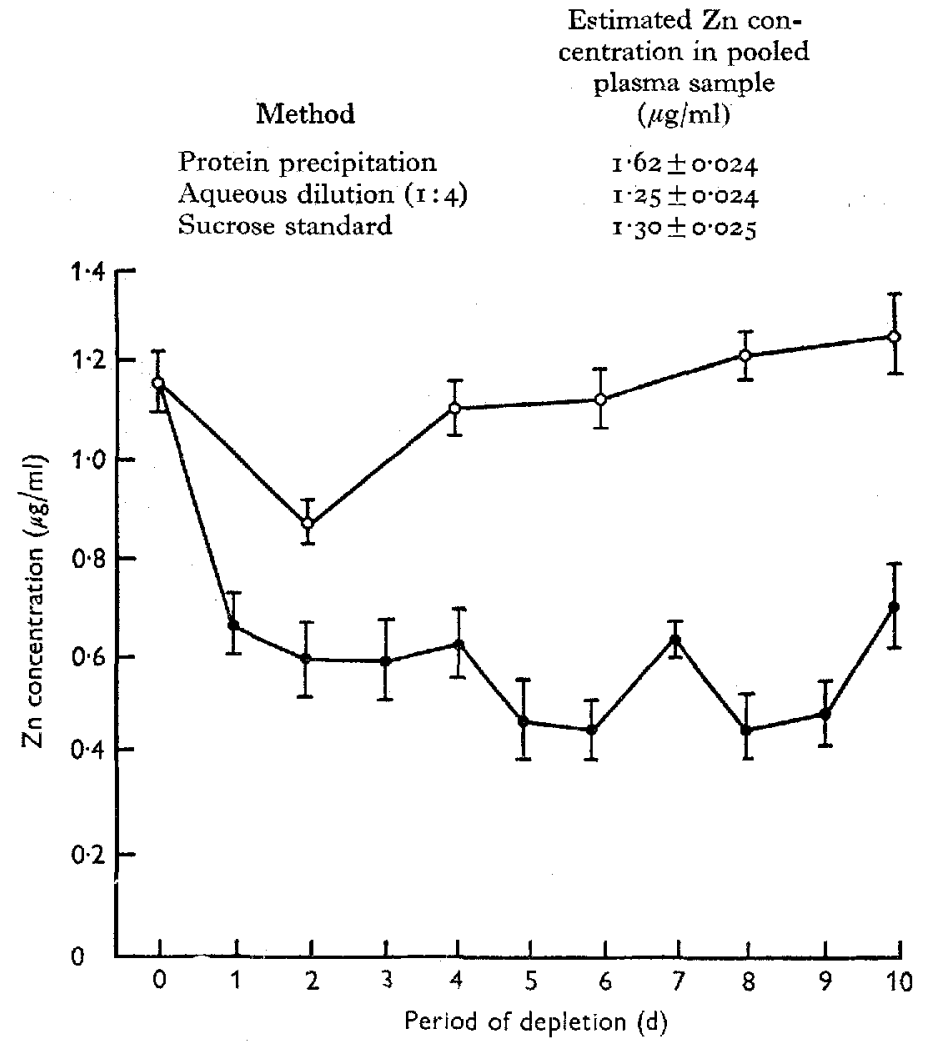

Fig. I. Concentration of plasma zinc in groups of rats after increasing periods on a $\mathrm{Zn-}$ deficient $(<0.25 \mathrm{ppm})$ or a $\mathrm{Zn}$-supplemented $(60 \mathrm{ppm})$ diet. $\mathrm{O}-\mathrm{O}$, controls; $-\mathrm{Zn}$ depleted. The vertical bars represent the standard errors.

\section{Plasma $Z n$ during progressive $Z n$ depletion}

Plasma $\mathrm{Zn}$ concentrations were determined in groups of five to nine rats which were killed on successive days of dietary $\mathrm{Zn}$ depletion. Similar determinations were performed on control animals every 2 nd day. The results are presented in Fig. I and they indicate that the concentration of plasma $\mathrm{Zn}$ fell by approximately $40 \%$ within 
the Ist day of dietary restriction. Thereafter, the fall became less marked, and after $5 \mathrm{~d}$ the concentrations stabilized at about $50 \%$ of the control values. Plasma $\mathrm{Zn}$ concentrations in the Zn-supplemented animals also fell by about $23 \%$ after $2 \mathrm{~d}$ on the experimental diet but returned to original levels by day 4 .

\section{Response of plasma $Z n$ to the oral administration of zinc sulphate}

Groups of six rats were maintained on the $\mathrm{Zn}$-deficient diet for $2 \mathrm{~d}$ and $8 \mathrm{~d}$ periods. Thereafter, the animals were dosed by mouth with $100 \mu \mathrm{g} \mathrm{Zn}$ as zinc sulphate in I $\mathrm{ml}$ water. Plasma $\mathrm{Zn}$ concentrations were determined $\mathrm{I} \cdot 75 \mathrm{~h}$ later. Control animals were treated in the same way. Plasma $\mathrm{Zn}$ concentrations rose markedly in the depleted animals after dosing and showed increases of $292 \%$ in the $2 \mathrm{~d}$ group and $426 \%$ in the $8 \mathrm{~d}$ group (Table 3 ). Plasma $\mathrm{Zn}$ concentrations in control animals rose by about $30 \%$ following dosing.

Table 3. Concentration of plasma zinc $\mathrm{I} \cdot 75 h$ after a single oral dose of $100 \mu \mathrm{g}$ zinc sulphate in rats given a $Z n$-deficient or a $Z n$-supplemented diet

(Mean values with their standard errors for six animals in each group)

$\begin{array}{cccc}\text { Zn status } & \begin{array}{c}\text { Period on } \\ \text { diet } \\ \text { Control }\end{array} & \begin{array}{c}\text { Dose } \\ (\mu \mathrm{g} \mathrm{Zn})\end{array} & \begin{array}{c}\text { Plasma Zn } \\ (\mu \mathrm{g} / \mathrm{ml})\end{array} \\ & 2 & - & 0.91 \pm 0.059 \\ & 8 & - & 1 \cdot 11 \pm 0.075 \\ \text { Deficient } & 2 & 100 & 1 \cdot 24 \pm 0.164 \\ & 8 & 100 & 1.50 \pm 0.137 \\ & 2 & - & 0.61 \pm 0.050 \\ & 8 & - & 0.45 \pm 0.064 \\ & 2 & 100 & 2.41 \pm 0.114 \\ & 8 & 100 & 2.37 \pm 0.513\end{array}$

Time-course of the plasma $Z n$ response following oral dosing

Groups of two to three rats were deprived of $\mathrm{Zn}$ for $2 \mathrm{~d}$ before receiving a single dose of $100 \mu \mathrm{g} \mathrm{Zn}$ by mouth. Thereafter, plasma $\mathrm{Zn}$ concentrations were determined on different groups at increasing time intervals from $30 \mathrm{~min}$. The results are presented in Fig. 2 and they indicate that plasma $\mathrm{Zn}$ concentrations reached a maximum in both the deficient and the control animals $1 \cdot 75 \mathrm{~h}$ after dosing, although in the deficient group the magnitude of the response was far greater $(228 \%)$ than in the controls $(40 \%)$.

\section{Response of plasma $Z n$ to the oral administration of varying concentrations of zinc sulphate}

Groups of two to three rats were deprived of $\mathrm{Zn}$ for $2 \mathrm{~d}$ before receiving single oral doses of $\mathrm{Zn}$ in varying concentrations. Control animals were dosed similarly and plasma $\mathrm{Zn}$ concentrations of all groups were determined $\mathrm{I} \cdot 75 \mathrm{~h}$ after dosing. The plasma $\mathrm{Zn}$ concentration did not vary significantly with the oral dose of $\mathrm{Zn}$, and in most instances was higher in the deficient animals than in the controls (Table 4 ). 


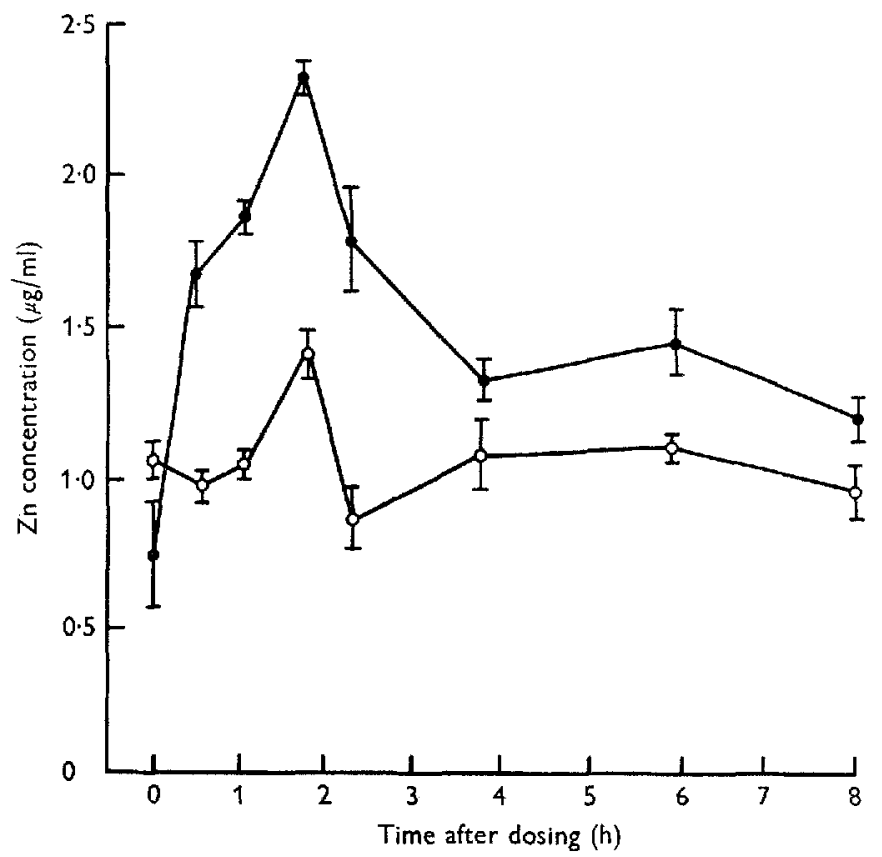

Fig. 2. Time-course of plasma zinc response in groups of rats after oral dosing with $100 \mu \mathrm{g}$ $\mathrm{Zn.} \mathrm{O}-\mathrm{O}$, controls;

Table 4. Concentration of plasma zinc $\mathrm{I} \cdot 75 \mathrm{~h}$ after varying doses of zinc sulphate in rats given a $Z n$-deficient or a $Z n$-supplemented diet for $2 d$ before dosing

(Values given for individual animals)

Dose
$(\mu \mathrm{g} \mathrm{Zn})$
20
50
75
100
150
200

\section{Control}

$0 \cdot 63,1 \cdot 63,1 \cdot 75$
$I \cdot 71, I \cdot 71$
$I \cdot 00, I \cdot 17, I \cdot 17$
$I \cdot 56, I \cdot 60,1 \cdot 60$
$I \cdot 17, I \cdot 25,1 \cdot 43$
$I \cdot 08, I \cdot 16, I \cdot 38$

Zn-deficient

$1 \cdot 40,2 \cdot 25,3.00$

I $-78,3 \cdot 25$

$I \cdot 25, x \cdot 37, x \cdot 65$

$2 \cdot 13,2 \cdot 20,2 \cdot 25$

I'I $3, I \cdot 90,2.08$

$2 \cdot 00,2 \cdot 34$

Table 5. Concentration of plasma zinc $\mathrm{x} \cdot 75 \mathrm{~h}$ after a single oral dose of $100 \mu \mathrm{g}$ zinc sulphate in rats given diets containing various levels of $Z n$ for $2 d$ before dosing

(Mean values with their standard errors for six animals in each group)

$\begin{array}{cc}\begin{array}{c}Z n \text { content } \\ \text { of diet } \\ (\mu \mathrm{g} / \mathrm{g})\end{array} & \begin{array}{c}\text { Plasma } \mathrm{Zn} \\ (\mu \mathrm{g} / \mathrm{ml})\end{array} \\ 0.25 & 2 \cdot 12 \pm 0.065 \\ \mathrm{I} \cdot 0 & 2 \cdot 11 \pm 0.110 \\ 3 \cdot 0 & 2 \cdot 25 \pm 0.014 \\ 5.0 & \mathrm{I} \cdot 91 \pm 0.113 \\ 7.0 & \mathrm{I} \cdot 77 \pm 0.117 \\ 10.0 & 1.07 \pm 0.078 \\ 25.0 & \mathrm{I} \cdot 10 \pm 0.100 \\ 60.0 & \mathrm{I} \cdot 10 \pm 0.071\end{array}$




\section{Response of plasma $Z n$ to oral dosing in rats at various stages of $Z n$ depletion}

Groups of six rats were maintained for $2 \mathrm{~d}$ on the basal $\mathrm{Zn}$-deficient diet supplemented with increasing amounts of $\mathrm{Zn}$ as zinc sulphate. Thereafter, all animals received IO0 $\mu \mathrm{g} \mathrm{Zn}$ in $\mathrm{I} \mathrm{ml}$ water by mouth and plasma $\mathrm{Zn}$ concentrations were determined $\mathrm{I} \cdot 75 \mathrm{~h}$ later (Table 5 ). The characteristic response associated with $\mathrm{Zn}$ deficiency was observed only in those animals receiving less than Io ppm of dietary $\mathrm{Zn}$.

\section{DISCUSSION}

Viscosity and sucrose standards

Although for many reasons plasma provides the tissue of choice for $\mathrm{Zn}$ analyses, its viscosity renders it unsuitable for direct comparison with aqueous standards. Deproteinization of plasma samples (Prasad et al. 1965) or their dilution with distilled water (Dreosti et al. 1968) and dilute hydrochloric acid (Girard, I968; Dawson \& Walker, I969) have been used with some success to overcome the effect of protein on sample nebulization. However, deproteinization is time-consuming and increases the risk of contamination, while the dilution techniques reduce the amount of $\mathrm{Zn}$ in plasma, especially in samples taken from $\mathrm{Zn}$-deficient animals, to concentrations ranging from $0 \cdot$ I to $0.3 \mathrm{ppm}$ which are not conveniently measured by most atomic absorption spectrophotometers.

In the present study, attention was accordingly focused on the use of undiluted plasma together with standard $\mathrm{Zn}$ solutions of similar viscosity. Dextran has previously been suggested (Hackley, Smith \& Halsted, rg68) to raise the viscosity of the standard solutions, although with this material the problems of contamination and polymer heterogeneity should not be underemphasized. We consider sucrose to be a better choice of solute as it is readily obtained in highly purified form and it is completely homogeneous. Viscosity measurements at $25^{\circ}$ showed that a $14 \%$ sucrose solution had a viscosity similar to that of pooled rat plasma. A comparison of the deproteinization, dilution and sucrose standard methods for plasma $\mathrm{Zn}$ measurements indicates a close agreement between the dilution and the sucrose standard methods, whereas results from the protein precipitation technique appeared to be somewhat higher $(24-29 \%)$. Possibly, the disparity reflects some degree of contamination in the latter samples, which highlights the need for a minimum of sample manipulation before assay.

\section{Plasma $Z n$ during progressive $Z n$ depletion}

It has previously been reported that in calves and lambs (Mills et al. 1967) and in rats (Dreosti et al. I968) plasma $\mathrm{Zn}$ concentration falls rapidly (40-60\%) following dietary restriction. The present findings confirm these reports and indicate that with $\mathrm{Zn}$, unlike with other elements, a low plasma concentration rapidly follows a reduced dietary intake. The recent findings of Parisi \& Vallee (1970) have shown that $30-40 \%$ of the plasma $\mathrm{Zn}$ is firmly bound to an $\alpha_{2}$-macroglobulin, whereas $60-70 \%$ is loosely bound to the albumin. It is probably the loosely bound fraction that accounts for the 
initial rapid fall in $\mathrm{Zn}$ concentration, whereas the firmly bound portion persists even during periods of $\mathrm{Zn}$ depletion.

In the present studies (Fig. $x$, Table 3 ) plasma Zn concentrations in the control rats were found to fall temporarily by about $23 \%$ after $2 \mathrm{~d}$. Possibly, the decline reflects an initial effect of the soya-bean meal on the availability of $\mathrm{Zn}$ from the control ration. The use of soya-bean meal and not isolated soya-bean protein in the present diets would have introduced high levels of plant material and possibly phytates into the diet.

The sensitivity of plasma $\mathrm{Zn}$ concentration to dietary intake is of considerable value as a diagnostic tool. However, the inherent variability between individuals usually renders a diagnosis extremely difficult - especially at the incipient or marginal level. A method was therefore sought whereby the $Z \mathbf{n}$ status of a single animal could be determined without recourse to extensive preliminary sampling.

\section{Response of plasma $Z n$ to the oral administration of zinc sulphate}

Earlier work on the diagnosis of copper deficiency in rats (Dreosti \& Quicke, 1968) has pointed to the practicality of a technique based on the response of plasma concentrations to a single oral dose of copper. In the present studies a similar response was observed with $\mathrm{Zn}$-depleted animals. Large rises in plasma $\mathrm{Zn}$ concentrations occurred following dosing of the deficient animals but a considerably smaller response was noted with the controls.

The response extended over a wide range of dose levels and notwithstanding the present uncertainty (Sandstead, 1968) may support the view that enhanced absorption of $\mathrm{Zn}$ occurs in depleted animals (Pate, Miller, Blackmon \& Gentry, 1970). The magnitude of the response, however, was not increased by increasing the dose, which may suggest that, if absorption was increased, the mechanism of uptake may have become limiting at the lower dose levels. Also, the response did not occur in rats fed on a diet containing Io $\mathrm{ppm}$ or more of $\mathrm{Zn}$ before dosing, although diets providing less than this amount elicited the response. The findings are of interest in view of the dietary requirements of rats suggested by other workers which range from 8 to I $8 \mathrm{ppm}$ (Underwood, I962).

The present findings suggest that the difference in plasma $\mathrm{Zn}$ concentrations before and after dosing with $\mathrm{Zn}$ could provide a useful method for the detection of a subnormal $\mathrm{Zn}$ status in a particular individual, without the need for extensive determinations of species or breed norms and the natural variation between individuals within the group. The applicability of these findings to other species, especially to ruminants, must await further investigation, but it is hoped that these findings with rats will pave the way for the development of a more effective method for the detection of a marginal $\mathrm{Zn}$ depletion in farm animals.

The authors wish to express their thanks to Libra Chemicals Pty Ltd and to the Mooi River Farmers' Association for the research bursaries awarded to P.J.W. and P.C.G. for $197^{\circ-I}$. 


\section{REFERENCES}

Davis, P. N., Norris, L. C. \& Kratzer, F. H. (1962). F. Nutr. 78, 445.

Dawson, J. B. \& Walker, B. E. (1969). Clinica chim. Acta 26, 465.

Dreosti, I. E. \& Quicke, G. V. (1968). Br. $Y$. Nutr. 22, r.

Dreosti, I. E., Tao, S. \& Hurley, L. S. (I968). Proc. Soc. exp. Biol. Med. 128, r69.

Girard, M. L. (1968). Clinica chim. Acta 20, 243.

Hackley, M. B., Smith, J. C. \& Halsted, J. A. (rg68). Clin. Chem. I4, I.

Hurley, L. S. (1969). Am. F. clin. Nutr. 22, r 332.

Hurley, L. S. \& Swenerton, H. (1966). Proc. Soc. exp. Biol. Med. 123, 692.

Mills, C. F., Dalgarno, A. C., Williams, R. B. \& Quarterman, J. (I967). Br. F. Nutr. 2r, 75 r.

Mills, C. F., Quarterman, J., Chesters, J. K., Williams, R. B. \& Dalgarno, A. C. (1969). Am. F. clin. Nutr. 22, 1240 .

Parisi, A. F. \& Vallee, B. L. (1970). Biochemistry, Easton 9, 2421.

Pate, F. M., Miller, W. J., Blackmon, D. M. \& Gentry, R. P. (1970). F. Nutr. 10o, 1259.

Prasad, A. S., Oberleas, D. \& Halsted, J. A. (r965). F. Lab. clin. Med. 66, 508.

Sandstead, H. H. ( ( 968). Nutrition Today 3, i2.

Swenerton, H. \& Hurley, L. S. (I 968), $\mathscr{F}$. Nutr. $95,8$.

Underwood, E. J. (1962). Trace Elements in Human and Animal Nutrition 2nd ed. New York: Academic Press Inc. 